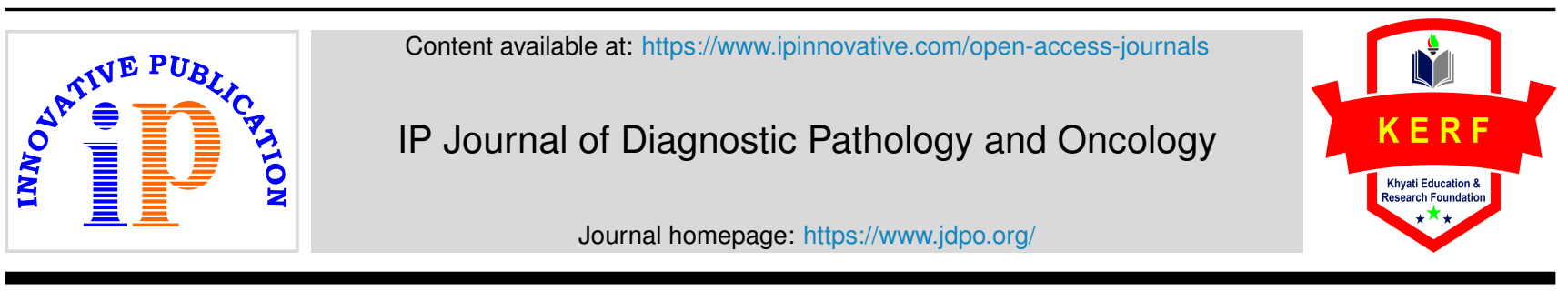

Original Research Article

\title{
Cliniopathological profile in women with abnormal uterine bleeding
}

\author{
Akshata A.C ${ }^{1, *}$, Bindu Rani K.M ${ }^{1}$ \\ ${ }^{1}$ Dept. of Pathology, Vijayanagar Institute of Medical Sciences (VIMS), Bellary, Karnataka, India
}

\section{A R T I C L E I N F O}

\section{Article history:}

Received 15-12-2020

Accepted 21-12-2020

Available online 10-03-2021

\section{Keywords:}

Abnormal uterine bleeding proliferative phase complex hyperplasia with atypia endometrial carcinoma endometrial polyp

\begin{abstract}
A B S T R A C T
Introduction: Abnormal uterine bleeding is a challenging gynecological problem caused by various endometrial pathologies and is a major clinical problem among women in peri and postmenopausal age groups. The problem is common worldwide but causes may vary from one region to another.

Aims and Objectives: The main objective was to evaluate pathological spectrum of different endometrial lesions in abnormal uterine bleeding and to correlate with clinical history and diagnosis.

Materials and Methods: The study was a prospective study done from August 2017 to July 2019. The specimens received from endometrial biopsy were included in the study. All the specimens were fixed in formalin and processed through paraffin wax embedding method. Sections were cut at 3-5 micrometer thickness and stained by Hematoxylin and Eosin (H\&E) stain and were examined under light microscope. Result: A total no. of 247 cases were studied. Out of these, 57 cases were of Proliferative endometrium, 33 cases of Secretory endometrium, 34 cases of simple hyperplasia without atypia, 11 cases of cystic glandular hyperplasia, 17 cases of complex hyperplasia with atypia, 09 cases of menstrual phase endometrium, 07 cases of irregular shedding, 06 cases of endometrial polyp and anovulatory cycle, 04 cases of endometritis, 03 cases each of simple hyperplasia with atypia, progesterone exposed endometrium and inadequate secretory phase, 02 cases each of complex hyperplasia without atypia, atrophic endometrium, products of conception and inadequate proliferative phase and 01 case each of stromal hyperplasia. 45 samples were inadequate. Maximum cases of abnormal uterine bleeding were seen between 31-40 years of age.

Interpretation and Conclusion: Abnormal uterine bleeding is one of the commonest condition for which patients seek advice in the gynecological outpatient department. Analysis of histopathology of endometrium in abnormal uterine bleeding helps in management of patients and to know the pathological incidence of structural causes in AUB prior to surgery.
\end{abstract}

(C) This is an open access article distributed under the terms of the Creative Commons Attribution License (https://creativecommons.org/licenses/by/4.0/) which permits unrestricted use, distribution, and reproduction in any medium, provided the original author and source are credited.

\section{Introduction}

The endometrium is uniquely endowed throughout the female reproductive lifespan with a complex of periodic proliferation, differentiation, breakdown and regeneration. ${ }^{1}$ Abnormal uterine bleeding (AUB) is a symptom and not a disease and it accounts for more than $70 \%$ of all gynecological consultations in the perimenopausal and postmenopausal age group. ${ }^{2}$ AUB is defined as changes in frequency of menstruation, duration of flow or amount of blood loss. ${ }^{3}$ It includes both dysfunctional

\footnotetext{
* Corresponding author.

E-mail address: akshataac10@gmail.com (Akshata A.C).
}

uterine bleeding (DUB) and bleeding from structural causes like fibroids, polyps, endometrial carcinoma, and pregnancy complications. ${ }^{4}$ It occurs in various forms such as menorrhagia, polymenorrhea, polymenorrhagia, metrorrhagia, and menometrorrhagia. ${ }^{2}$ Endometrium is a hormonally sensitive, dynamic and responsive tissue which constantly and rhythmically undergoes changes in the active reproductive life. ${ }^{5}$ Wide range of morphologic patterns resulting from both normal and abnormal changes offer a diagnostic challenge to practicing pathologists. Endometrial samplings by dilatation and curettage, endometrial biopsy, pipelle and hysterectomy specimens are chosen methods to evaluate AUB. 


\section{Aims and Objectives}

To find out the pathological spectrum of different endometrial lesions in Abnormal uterine bleeding and Correlation of different pathological findings with clinical history and examination.

\section{Materials and Methods}

Detailed clinical history and relevant diagnostic findings were collected from patients presenting with abnormal uterine bleeding during a period of two years, from August 2017 to July 2019. All specimens were transported in 10\% formalin to the Department of Pathology, VIMS Bellary. The tissue bits were processed and paraffin blocks were prepared. Tissue sections (3-5 $\mu$ ) were cut and stained with hematoxylin and eosin stain (H\&E). A detailed histological study was carried out and the findings were noted and classified.

\section{Results}

The study material included a total number of 247 endometrial samples (endometrial curettage and biopsy). Age range in the study group was from 22 years to 70 years, thus including reproductive to postmenopausal age group with more number of cases seen to be clustered in reproductive age group (Table 1). Predominant histopathological pattern noted was proliferative endometrium (Figure 1) seen in $23.1 \%$ cases (Table 2).

Out of 247 cases, only 200 cases were included in our table, after excluding non-diagnostic cases. Out of 200 cases, 126 cases were non neoplastic and 74 cases were pre- neoplastic/ neoplastic (Table 3). Under non neoplastic conditions, proliferative phase endometrium (57 cases) was most common finding and simple hyperplasia was documented as most common finding under pre neoplastic conditions (Figure 2).

Hyperplasia was observed in 67 cases (Table 4), simple hyperplasia was most common which includes cystic glandular hyperplasia and of 67 hyperplasia, 20 cases presented with atypia (Figure 3)

Table 1: Distribution of cases in different age categories

\begin{tabular}{lcc}
\hline Category & No. of cases & Percentage \\
Reproductive & 136 & 55.1 \\
Perimenopausal & 75 & 30.4 \\
Postmenopausal & 36 & 14.6 \\
Total & 247 & 100 \\
\hline
\end{tabular}

\section{Discussion}

Endometrial sampling is an indispensable and an outstanding tool in the assessment of underlying pathology in patients with AUB. The main purpose of endometrial
Table 2: Analysis ofhistopathological findings in endometrial biopsy samples

\begin{tabular}{|c|c|c|c|}
\hline S. No & Histological feature & $\begin{array}{l}\text { No. of } \\
\text { cases }\end{array}$ & Percentage \\
\hline 1 & Proliferative phase & 57 & 23.1 \\
\hline 2 & Secretory phase & 33 & 13.4 \\
\hline 3 & Menstrual phase & 9 & 3.6 \\
\hline 4 & Endometrial polyp & 6 & 2.4 \\
\hline 5 & $\begin{array}{l}\text { Progesterone exposed } \\
\text { endometrium }\end{array}$ & 3 & 1.2 \\
\hline 6 & Anovulatory Cycle & 6 & 2.4 \\
\hline 7 & Irregular shedding & 7 & 2.8 \\
\hline 8 & $\begin{array}{l}\text { Inadequate secretory } \\
\text { phase }\end{array}$ & 3 & 1.2 \\
\hline 9 & $\begin{array}{l}\text { Inadequate } \\
\text { proliferative phase }\end{array}$ & 2 & 0.8 \\
\hline 10 & Endometritis & 4 & 1.6 \\
\hline 11 & Atrophic & 2 & 0.8 \\
\hline 12 & Stromal hyperplasia & 1 & 0.4 \\
\hline 13 & $\begin{array}{l}\text { Cystic glandular } \\
\text { hyperplasia }\end{array}$ & 11 & 4.5 \\
\hline 14 & Simple hyperplasia & 34 & 13.8 \\
\hline 15 & $\begin{array}{l}\text { Simple hyperplasia } \\
\text { with atypia }\end{array}$ & 3 & 1.2 \\
\hline 16 & Complex hyperplasia & 2 & 0.8 \\
\hline 17 & $\begin{array}{l}\text { Complex hyperplasia } \\
\text { with atypia }\end{array}$ & 17 & 6.9 \\
\hline 18 & $\begin{array}{l}\text { Products of } \\
\text { conception }\end{array}$ & 2 & 0.8 \\
\hline 19 & Inadequate & 45 & 18.2 \\
\hline Total & & 247 & 100.0 \\
\hline
\end{tabular}

Table 3: Distribution of Pre-neoplastic and Non neoplastic conditions

\begin{tabular}{lclc}
\hline \multicolumn{2}{l}{$\begin{array}{l}\text { Non neoplastic conditions } \\
\text { Proliferative phase }\end{array}$} & 57 & \multicolumn{2}{l}{ Pre neoplastic conditions } \\
Secretory phase & 33 & $\begin{array}{l}\text { Simple hyperplasia } \\
\text { Sith hyperplasia }\end{array}$ & 34 \\
Menstrual phase & 9 & $\begin{array}{l}\text { Complex hyperplasia } \\
\text { without atypia }\end{array}$ & 2 \\
$\begin{array}{l}\text { Progesterone } \\
\text { exposed }\end{array}$ & 3 & $\begin{array}{l}\text { Complex hyperplasia } \\
\text { with atypia }\end{array}$ & 17 \\
$\begin{array}{l}\text { endometrium } \\
\text { Anovulatory }\end{array}$ & 6 & $\begin{array}{l}\text { Cystic glandular } \\
\text { hyperplasia }\end{array}$ & 11 \\
$\begin{array}{l}\text { Irregular shedding } \\
\text { Inadequate secretory } \\
\text { phase }\end{array}$ & 7 & $\begin{array}{l}\text { Stromal hyperplasia } \\
\text { Endometrial polyp }\end{array}$ & 1 \\
$\begin{array}{l}\text { Inadequate } \\
\text { proliferative phase }\end{array}$ & 2 & & 6 \\
$\begin{array}{l}\text { Endometritis } \\
\text { Atrophic }\end{array}$ & 4 & & 74 \\
Total & 2 & & \\
\hline
\end{tabular}




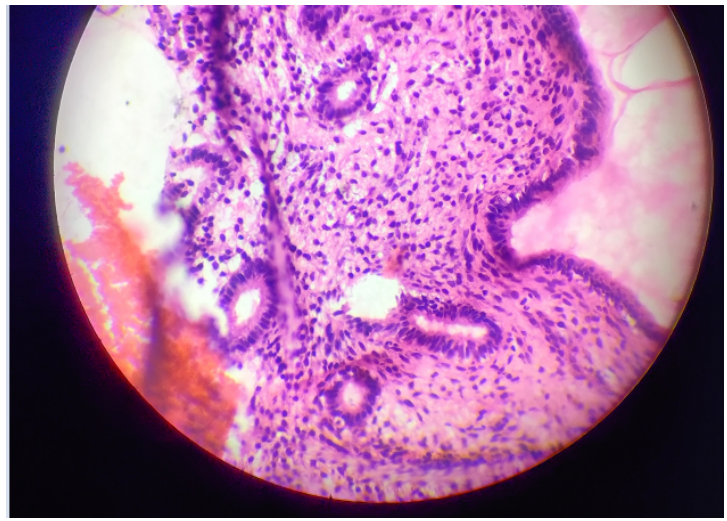

Fig. 1:

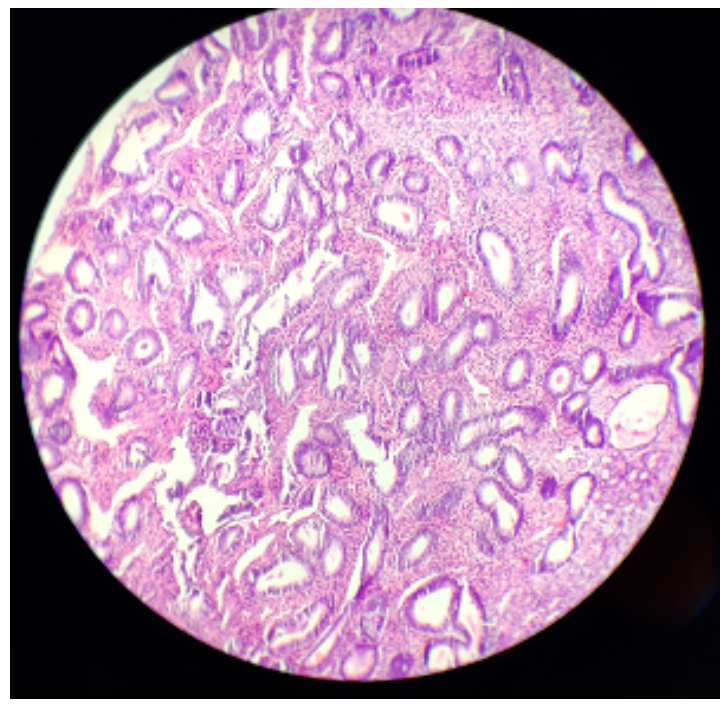

Fig. 2:

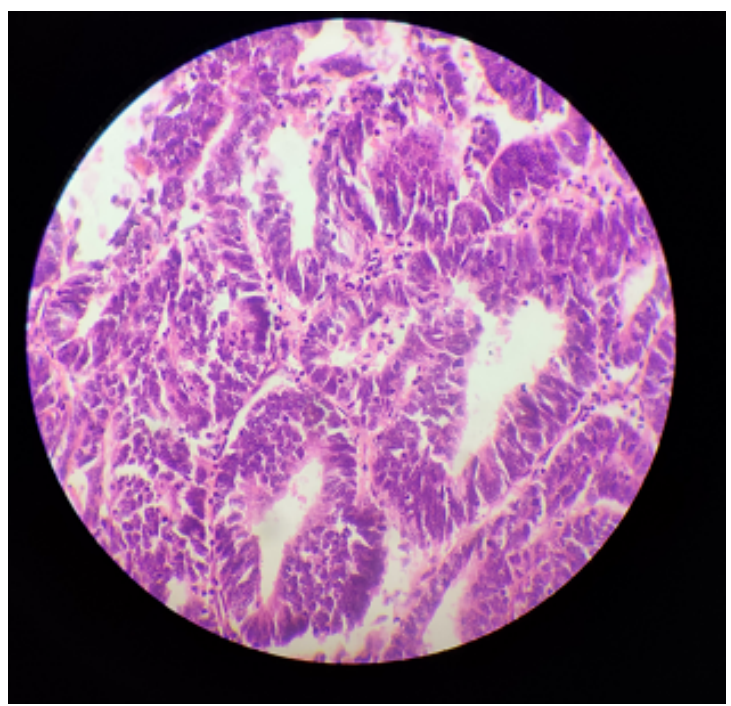

Fig. 3:
Table 4: Types of Hyperplasia

\begin{tabular}{|c|c|c|c|}
\hline S. No & $\begin{array}{l}\text { Type of } \\
\text { Hyperplasia }\end{array}$ & $\begin{array}{l}\text { No. of } \\
\text { cases }\end{array}$ & $\begin{array}{c}\text { Percentage } \\
(\%)\end{array}$ \\
\hline 1 & Simple hyperplasia & 34 & 50.75 \\
\hline 2 & $\begin{array}{l}\text { Simple hyperplasia } \\
\text { with atypia }\end{array}$ & 3 & 4.48 \\
\hline 3 & $\begin{array}{l}\text { Complex } \\
\text { hyperplasia without } \\
\text { atypia }\end{array}$ & 2 & 2.98 \\
\hline 4 & $\begin{array}{l}\text { Complex } \\
\text { hyperplasia with } \\
\text { atypia }\end{array}$ & 17 & 25.38 \\
\hline 5 & $\begin{array}{l}\text { Cystic glandular } \\
\text { hyperplasia }\end{array}$ & 11 & 16.41 \\
\hline Total & & 67 & 100 \\
\hline
\end{tabular}

Table 5: Comparative study of incidence of endometrial hyperplasia in AUB

\begin{tabular}{lcc}
\hline Authors & Year & $\begin{array}{c}\text { Percentage of cases of } \\
\text { hyperplasia in } \\
\text { endometrial samples }\end{array}$ \\
Mehrotra $^{6}$ & 1972 & $19.4 \%$ \\
Saraswathi & 2011 & $6.1 \%$ \\
$\begin{array}{l}\text { Doraiswami } \\
\text { Bolde SA et al }^{8}\end{array}$ & 2014 & $19.40 \%$ \\
Gorla P et al $^{9}$ & 2016 & $10.37 \%$ \\
Present study $^{8}$ & 2019 & $27.12 \%$ \\
\hline
\end{tabular}

sampling is early detection of endometrial hyperplasia and carcinoma. $^{2}$

The age distribution of AUB in our study revealed that most of the cases were seen in 31-40 years of age group which is in concordance with study done by Mitali Mahapatra et al ${ }^{10}$ and Hetal et al. ${ }^{11}$ The number of cases of AUB in the age group of $>50$ years $(14.6 \%)$ which is almost similar to the data mentioned by Smita S. Pudale et al. ${ }^{8}(14.3 \%)$ and Bindroo $\mathrm{S}$ et al. ${ }^{12}$ (13.2\%)

Proliferative phase $(23.1 \%)$ was most common histopathologic pattern, similar observations were made by Sadia Khan et al ${ }^{13}(46.6 \%)$, Mitali Mahapatra et al ${ }^{10}$ (45.70\%), Hetal Rajendra Patel et al ${ }^{11}(47.69 \%)$ but with a higher incidence.

Incidence of endometrial polyp was seen in $2.4 \%$ of cases in our study which is comparable with that of Shruti Singh et $\mathrm{al}^{14}(4.8 \%)$ and Rehana Khan et al ${ }^{15}(3.33 \%)$. Atrophic endometrium in the present study comprised of $0.80 \%$ cases of AUB while its incidence was higher in study done by Bhatta S et al ${ }^{3}(7.38 \%)$ and Jairajpuri ZS et al ${ }^{5}(1.10 \%)$.

Endometrial hyperplasia was observed in $27.12 \%$ of cases. Present study shows a higher incidence of hyperplasia when compared with the studies (Table 5). ${ }^{6,7,9,12}$ In the present study it was noted that hyperplasia without atypia were more common in cases $<40$ years of age while hyperplasia with atypia were most commonly seen in cases $>40$ years of age. 


\section{Conclusion}

Malignancy in particular is common in patients over 40 years of age. Hence the histopathological study of endometrium in abnormal uterine bleeding in women above the age of 40 years plays an important role in diagnosing various histological patterns and aetiopathological factors. A comparative clinicopathological study will help in arriving at the cause and correct diagnosis, proper management of cases.

\section{Source of Funding}

No financial support was received for the work within this manuscript.

\section{Conflict of Interest}

The authors declare that they have no conflict of interest.

\section{References}

1. Salvi A, Mital P, Hooja N, Batar A, Soni P, Beniwal R, et al. Spectrum of Endometrial Histopathology in Women Presenting with Abnormal Uterine Bleeding. Sch J App Med Sci. 2015;3(1A):1-4.

2. Talukdar B, Mahela S. Abnormal uterine bleeding in perimenopausal women: Correlation with sonographic findings and histopathological examination of hysterectomy specimens. $J$ Mid-life Health. 2016;7(2):73-7. 100:10.4103/0976-7800. 185336

3. Bhatta S, Sinha AK. Histopathological study of endometrium in abnormal uterine bleeding. J Pathol Nepal. 2012;2(4):297-300. doi:10.3126/jpn.v214.6882

4. Jairajpuri ZS, Jetley S, Rana S. Morphological spectrum of endometrial pathology in middle-aged women with atypical uterine bleeding: A study of 219 cases. J Mid-life Health. 2013;4(4):216-20. doi: $0.4103 / 0976-7800.22242$

5. Jairajpuri ZS, Rana S, Jetley S. Atypical uterine bleedingHistopathological audit of endometrium: A study of 638 cases. Al Ameen J Med Sci. 2013;6(1):21-8.

6. Mukherjee K, Pandey M. Functional Uterine bleeding - (A Review of 150 cases). J Obstet Gynaecol India. 1972;22:684-9.
7. Doraiswami S, Johnson T, Rao S, Rajkumar A, Vijayaraghavan J, Panicker VK, et al. Study of Endometrial Pathology in Abnormal Uterine Bleeding. J Obstet Gynecol India. 2011;61(4):426-30. 10:-10.1007/s [3224-0] [-0047-2

8. Bolde SA, Pudale S, Pandit G, Matkari P. Histopathological study of endometrium in cases of abnormal uterine bleeding. Int J Res Med Sci . 2014;2(4):1378-81. do1:10.5455/2320-6012.1]rms20141125.

9. Gorla P, Sanapala S, Devi E, Atla B, Rasaputra M. Histopathology of endometrium in abnormal uterine bleeding, in correlation with thyroid profile and ultrasonography findings. Int J Res Med Sci . 2016;4:14639. doi:10.18203/2320-6012.1jrms20161211.

10. Mahapatra M, Mishra P. Clinicopathological evaluation of abnormal uterine bleeding. J Health Res Rev . 2015;2(2):45-9.

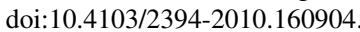

11. Patel HR. Histopathological patterns of endometrial lesions in patients with abnormal uterine bleeding- study of 500 cases. Int J Biol Med Res. 2017;8(2):5995-6002.

12. Bindroo S, Garg M, Kaur T. Histopathological spectrum of endometrium in abnormal uterine bleeding. Int $J$ Reprod Contracept Obstet Gynecol. 2018;7(9):3633-7. 101010.8203/2320 [17/0.1][rog20183767.

13. Khan S, Hameed S, Umber A. Histopathological Pattern of Endometrium on Diagnostic D \& C in Patients with Abnormal Uterine Bleeding. Annls. 2011;17(2).

14. Singh S, Pandey P, Agarwal S, Kaur S, Singh S. Spectrum of uterine lesions presenting as abnormal uterine bleeding in a rural north Indian population: a study from tertiary care center. Int J Res Med Sci. 2016;4:3250-4.

15. Khan R, Sherwani R, Hakim RS, Jairajpuri S, Z. Clinco-Pathological Patterns in Women with Dysfunctional Uterine Bleeding. Iran J Pathol . 2016;11(1):20-6.

\section{Author biography}

Akshata A.C, Senior Resident

Bindu Rani K.M, Associate Professor

Cite this article: Akshata A.C, Rani K.M B. Cliniopathological profile in women with abnormal uterine bleeding. IP J Diagn Pathol Oncol 2021;6(1):15-18. 